Отримано: 9 вересня 2019 року

Прорецензовано: 16 вересня 2019 року

Прийнято до друку: 23 вересня 2019 року

e-mail: victory_star.86@mail.ru

DOI: $10.25264 / 2519-2558-2019-7(75)-145-147$
Sobolevich V. Yu. Formation of professional foreign language competence of students studying at non-linguistic specialties in a higher education institution. Наукові записки Національного університету «Острозька академія»: серія «Філологія». Острог: Видво НаУОА, 2019. Вип. 7(75), жовтень. С. 145-147.

Victoria Sobolevich,

\title{
FORMATION OF PROFESSIONAL FOREIGN LANGUAGE COMPETENCE OF STUDENTS STUDYING AT NON-LINGUISTIC SPECIALTIES IN A HIGHER EDUCATION INSTITUTION
}

The problem of forming professional foreign competence of students studying at non-linguistic specialties in a higher education institution is described in the article; structural components of professional foreign language communicative competence and the models of communication in the professional sphere are defined and described. The article shows the experience and examples of work of English language department teachers of the education establishment "Francisk Skorina Gomel State University", methods, approaches, materials and models of communication used by them to achieve the main goal. The real practical advantages of mastering professional foreign language competence are considered and the examples of its possible use in the further professional career of a higher education institution graduate are given.

Key words: communicative competence, professional foreign language competence, communication skills, professional communication.

\section{Соболевіч Вікторія Юріівна,}

викладач

Гомельський Державний Університет імені Ф. Скорини\&qиот

\section{ФОРМУВАННЯ ПРОФЕСІЙНОЇ ІНШОМОВНОЇ КОМПЕТЕНЦІІ У СТУДЕНТІВ НЕМОВНИХ СПЕЦІАЛЬНОСТЕЙ У ВНЗ}

У статті розкриваеться проблема формування професійної іншомовної компетенції у студентів немовних спеціальностей у вузі; визначаються і описуються структурні компоненти професійної іншомовної комунікативної компетениії $і$ моделі спілкування в професійній сфері. У статті представлений досвід і приклади роботи викладачів кафедри англійської мови установи освіти «ГГУ ім. Ф. Скорини», використовувані ними методи, способи, матеріали і моделі спілкування для досягнення головної мети. Реальні практичні переваги оволодіння професійною іншомовною компетенцією розглядаються і наводяться приклади ії можливого використання в подальшій професійній кар 'єрі випускника вищого навчального закладу.

Ключові слова: комунікативна компетенція, професійна іншомовна компетениія, комунікативні вміння і навички, професійне спілкування.

In today's highly competitive business environment there is a dramatic increase in the demand for staff adapted to the constant changes in the global informatization processes. Modern conditions significantly affect all spheres of human social life, applying new requirements to the educational process. Nowadays a lot of demands are placed on a higher education institution graduate. They must meet all of them. They must be qualified employees of a certain level and profile, competitive, competent, have excellent skills of their profession and be oriented in related fields of activity, capable of efficient work in their specialty at the level of world standards.

The typical goals and objectives of foreign language training of students studying at non-linguistic specialties of higher education institutions of the Republic of Belarus are constantly changed due to the fast-paced world and the increasing demands for social and professional communication. At present there form such conditions in which the quality and level of training of a modern specialist are assessed. Competence, autonomy, willingness to make decisions in alternative choice situations, the ability to adapt to rapidly changing working conditions, the presence of motivation for lifelong education and professional growth in a competitive environment, professional responsibility, active participation in international professional partnership programs and integration are the indicators of particular importance. And they are always taken into account.

The communicative competence refers to a learner's ability to use language for successful communication. Canale and Swain defined it as composing competence in four areas:

- Words and rules;

- Appropriacy;

- Cohesion and coherence;

- Use of communication strategies [1, p. 5].

Communicative competence is defined in modern science as the integrative personal resource which provides success of communicative activity and includes not only the components measured by means of language testing, but also other components. These components are shown on higher personal level and include intelligence, the general outlook, system of the interpersonal relations, special professional knowledge, and also potential of personal formation and growth in mastering language and communicative activity

The formation of the communicative competence of the future specialist is the main goal of teaching a foreign language in non-linguistic specialties at higher education institution in accordance with the new needs of society and universal requirements establishing for the level of foreign language proficiency at the international level. This competency will allow them to use a foreign language as a means of professional and interpersonal communication in future. The communicative competence is realized in the 
process of learning a foreign language as a unity of all its constituent units: general (cognitive, strategic and social) and transitive (linguistic, verbal, sociocultural, intercultural, etc.).

The scientists (I.A. Zimnyaya, Y. I. Passov, G.P. Savchenko, V.V. Safonova and others) have been interested in the problem of formation of both communicative competence and professional communicative competence till present. The complex structure of a foreign-language professional communicative competence includes not only a system of communication skills, but also orientation in communicative means and aspects of human communication, knowledge of social norms of behavior, value navigators, customs and traditions of communicants speaking another language. The process of professional foreign language mastering directly provides with the acquisition of knowledge, skills and professional language behavior, learning the norms in various situations of professional communication and in different types of foreign-language professionally oriented speech activity. There occurs the gradual movement from artificial speech to natural. All these factors determine the formation of communicative competence.

Thus, professional and communicative competence is defined as a complex professional and personal language resource of students, ensuring their communication in a specific speech situation while observing modern language / speech standards, and also allowing regulating communicative behavior in the professional sphere of communication. Taking into account the basics of professional-speech communication, foreign language teaching contributes to the formation of professional-communicative competence among future specialists [2, p. 55].

It should be noted that the professional foreign language communicative competence of a specialist is a complex integrative compound. It provides professional communication in the specialty in the context of intercultural communication with the help of the following structural components:

- communicative one, implying the correct use in professional speech of linguistic socially marked units as well as the ability to choose a communication style and an adequate interpretation of the phenomena of a foreign language professional culture;

- professional one, which is expressed in the experience of performing professional functions as well as in the qualities of a person who plays a particular social (professional) role;

- reflective one, which consists in the ability to adjust one's own communicative behavior in accordance with situations of communicative and professional interaction;

- cognitive one, which includes a set of general professional knowledge, skills, abilities and methods of activity necessary for cognition of foreign cultural professional reality;

- psychological one, which consists in the formation of students' readiness for the implementation of a particular type of professional activity (role).

The effectiveness of the formation of professional communicative competence will depend on the integration of all future specialists' training goals. They should be aimed not only at combining the main course of a foreign language with professional subjects, but also at the reflexive interaction of the teacher and student.

Despite the pronounced tendency of professional teaching of a foreign language, a contradiction continues to occur between the growing need of society for improving foreign language literacy and the system of training that does not fully justify itself [4, $p$. 123]. However, the formation of the speech activity of a future specialist as a component of their general professional competence will be ineffective outside the social, professional and psychological contexts. According to V.D. Shadrikov, professional transitive and foreign language knowledge, skills and abilities which are assimilated by the student, but not interconnected by the logic of professional activity and not possessing the traits of "efficiency" act in relation to each other as psychological barriers that impede their instant integration, as required real life situations [5, p. 147].

When giving classes in the discipline "Foreign Language", the teachers of the English language department of the education establishment "Francisk Skorina Gomel State University" rely on the "Typical curriculum for higher education institutions of the Republic of Belarus". They distinguish two models of communication in the subject-thematic plan of this discipline. They are a model of social communication and a model of professional communication.

The teachers of the English language department take into account the structural components of intercultural communication at their classes. They use various audio recordings and video materials to introduce students studying at non-linguistic specialties to the culture and traditions of the country of the language being studied. Much attention is paid by the teachers of the department to the formation of sociolinguistic and sociocultural competence within the framework of the social communication model in the process of working on thematic material. The definition of sociocultural competence is the following: knowledge of national and cultural characteristics of the countries of studied language, norms of verbal and non-verbal behavior and ability to regulate the conduct in accordance with this knowledge in real-life situations of communication. Sociolinguistic competence has been an integral part of communicative competence in that it includes learning pragmatic and sociolinguistic knowledge about how to use language linguistically and socially appropriately. For example, when studying topic "London and its Places of Interest" the teachers of the department offer students to go on a virtual tour of the city using multimedia presentations or watching a movie. Then the students present and discuss the most remembered tradition, custom, dish, place of interest and famous person. The students draw parallels between the traditions of their native country and Britain and they also learn how to treat a different mentality and culture with tolerance and understanding. At the same time they develop speaking skills on this topic. Thus, when studying oral topics "Great Britain" and "London and its Places of Interest" the students studying at non-linguistic specialties of Fransick Skorina Gomel State University become familiar with:

1) the way and lifestyle in the country of the language being studied and the social values, norms, traditions and customs that are related to them;

2) sociocultural portrait of the country and the people of the language being studied;

3) spiritual, material and physical culture of Great Britain;

4) cultural heritage, cultural identity and mentality of the British;

While studying the topic "The Political System of the United Kingdom of Great Britain and Northern Ireland", students together with the teachers compare the political system of two countries: the Republic of Belarus and Great Britain. The discussion of the pros and cons of the monarchy makes it possible to understand the conservative nature of the British people and their commitment to traditions. 
The discussion of the role of the queen in society and the existence of the House of Lords help to trace the secure foundations of modern British society that is based on the continuity of traditions and customs. Special attention should be given to the ability to express the opinion in a foreign language correctly and unbiasedly in the modern process of cultures integrating in a multicultural society.

When studying the topic "The Education System of the United Kingdom", students studying at non-linguistic specialties get acquainted with the system of primary, secondary, specialized secondary and higher education in the United Kingdom, learn its features and compare it with the education system in the Republic of Belarus. Watching films about British universities can make them want to enter and study at them. And this, in its turn, stimulates the motivation for more successful studies at the native university. Students may also be interested in the presence of such a university in Britain as Open University, which provides the opportunity to study in a convenient place and at a convenient time. You can always hear the students' wishes for the creation of such a university in our republic.

The foreign language work program also provides for the study of social vocabulary on the topics "In the shop", "At the restaurant", "In the airport", "At the doctor's", "At the hotel" and others. That helps to communicate with the representatives of different countries. The study of this vocabulary can take place in various forms: dialogue, role-playing, staging, etc. While learning these topics, students, without realizing this, are introduced to the social and cultural norms that will be useful to them in the process of intercultural communication. It is important to use authentic material as much as possible so that students can make a true picture of the life of modern British people.

Students are offered a wide variety of texts in their chosen specialty to learn the professional vocabulary. The professional vocabulary is learnt in monological statements and in the form of dialogue with the formulation of a specific problem. For example, when giving classes to the students of the Faculty of Physical Education, written and oral forms of professional communication are imitated, dialogues on sports topics are made. The students read professionally oriented texts with a variety of post-text lexical and lexical-grammar exercises. So, when reading a text on a specialty from the original literature «Track-and-field» the students learn sports-oriented vocabulary: «The running events are categorised as sprints, middle and long-distance events, relays, and hurdling. Regular jumping events include long jump, triple jump, high jump and pole vault, while the most common throwing events are shot put, javelin, discus and hammer. There are also "combined events», such as heptathlon and decathlon» [3, p. 5] and then they do post-text exercises. For example, they should insert the missing words «Regular jumping events include , triple jump, high jump and " [3, p. 7].

When giving classes in a foreign language, the use of interactive methods provides with a high degree of activity and independence of all its participants. The following methods of interactive learning are used: business games, disputes, discussions, stage plays, conferences in a professionally oriented learning environment. They imitate those problematic situations that occur in the professional activity of a specialist in real conditions, thereby forming the professional component of intercultural communication. In this regard, it is very important to teach students business English. However, students' ability to use business English in situations of business intercultural communication can form subject to the use of interactive teaching methods. They involve learning in collaboration and contribute to the formation of personal and professionally significant qualities of students in relation to their professional business sphere.

Thus, when giving classes in a foreign language, teachers of the English language department create optimal conditions for the formation of professional foreign-language communicative competence among students studying at non-linguistic specialties. At the same time, they use interactive teaching methods that significantly activate the forms of educational activity, as they contribute to the involvement of most students in joint activities to achieve their goals, the emergence of a positive emotional state from cognitive communication, the awareness of the need to achieve and enter into this communication, and reduce anxiety and remove psychological barriers while speaking foreign language. This is how the psychological component of intercultural communication is formed. Teachers of the department also fulfill the main condition for using these methods at non-linguistic specialties of the higher education institution: their professional orientation and thematic connection with the main subjects. This is one of the possible ways to form a professional communicative competence, which allows you to increase students' interest in foreign language classes and optimize the learning process.

Training is carried out in our university aimed at developing students' professional foreign language competence upon receipt of professional knowledge in relevant specialties. Mastering professional foreign language competence allows students to have real practical advantages. A student with a high level of professional foreign language competence can use professional competencies of an informative and communicative nature in the field of wider communication in a foreign language, contacts and intercultural relations. They can participate in various international projects at a professional level, conduct professional interactive activities, work abroad at the same time increasing the level of their own well-being.

Thus, the formation of professional foreign language competence among students of non-linguistic specialties at the higher education institutions is one of the fundamental goals of training and education. It involves the training of highly qualified specialists who are ready for interaction in the professional field of communication, for continuous communicative and professional growth as well as for social and professional mobility. The teachers of the English language department of "Francisk Skorina Gomel State University" try to find new methods and ways of forming professional foreign-language communicative competence. They take into account the needs of society, directly of the students themselves, apply interactive teaching methods, give classes of various types, and thus try to prepare highly qualified specialists with the formed professional foreign language competence.

\section{References}

1. Canale M., Swain M. Theoretical Bases of Communicative Approaches to Second Language Teaching and Testing. Applied Linguistics, 1. 1980. $47 \mathrm{p}$.

2. Izarenkov D. I. Basic components of communicative competence and their formation at an advanced stage of training of students studying at non-linguistic specialties. Russian language abroad. 1990. No. 4. P. $54-60$.

3. Kazimirskiy G. L., Protopopova T. V., Starokozheva V. Y. The English language: Application for the students of specialty 1-03-02 01 "Physical culture". Gomel: EE "Fransick Skorina Gomel State University", 2011. 48 p.

4. Tenischeva V. F. Integrative and contextual model of the formation of professional competence: extended extract of Doctor of Pedagogical Sciences dissertation: 16.00.09. Moscow, 2008. 143 p.

5. Shadrikov V. D. Professional abilities. Moscow: University Book, 2010. 344 p. 